\title{
Infusing Reconciliation into the Sentencing Process
}

\section{Colton Fehr ${ }^{*}$}

\section{Introduction}

The Criminal Code of Canada $a^{1}$ provides that the fundamental purpose of sentencing is to promote "respect for the law and the maintenance of a just, peaceful and safe society". ${ }^{2}$ Sentencing judges accomplish these goals by imposing sanctions that further traditional sentencing objectives such as denunciation, deterrence, rehabilitation, reparation, promoting a sense of responsibility in offenders, and, where necessary, separating offenders from society. ${ }^{3}$ In utilizing these sentencing tools, judges are guided by the fundamental principle of sentencing: proportionality. ${ }^{4}$ This principle requires not only proportionality between the penalty imposed and the gravity of the offence; the punishment must also be commensurate with the moral blameworthiness of the offender. ${ }^{5}$

A fundamental aspect of achieving proportionality in sentencing is enshrined in section 718.2(e) of the Criminal Code. It provides that "all available sanctions, other than imprisonment, that are reasonable in the circumstances and consistent with the harm done to victims or to the community should be considered for all offenders, with particular attention to the circumstances of Aboriginal offenders." In both $R$ $v$ Gladue $^{6}$ and $R v$ Ipeelee, $^{7}$ the Supreme Court of Canada emphasized the need for trial judges to consider the effect of Canada's colonial history on its First Nations people. ${ }^{8}$ As the Court observed, the inadequate progress made by Canadian society in addressing the overincarceration of First Nations people may aptly be described as a "crisis in the Canadian criminal justice system."

While it is of the utmost importance to ensure First Nations peoples are not overrepresented in the criminal justice system, ${ }^{10}$ it is also necessary to consider the process of sentencing and how it too fails to further the aim of reconciling relations with First Nations persons. In particular, I want to problematize a basic feature of how Canadian courts go about sentencing, namely, the order in which lawyers make sentencing submissions. For anyone who has ever attended a sentencing hearing in Canada, that order typically involves the Crown speaking, defence counsel responding, and the judge passing sentence. I think we might do better by reversing the order in which counsel speaks.

To better understand this argument, it is necessary to first provide some detail about how the Canadian sentencing system operates. After so doing, I will explain why a First Nations person might reasonably believe that the Crown Prosecutor, the representative of the state, does not care to hear about their circumstances before providing a court with sentencing submissions. I contend that reversing the order would require Crown Prosecutors to hear about a First Nations person's circumstances, and respond to those circumstances, when addressing the court. This in turn is more likely to make offenders genuinely feel like the Crown considers their personal circumstances before recommending a sentence. This point might seem minor. For those who have lost faith in the Canadian criminal 
justice system, however, it should provide some hope that the system wants to engage with First Nations peoples and their experiences.

\section{A Dose of (Sentencing) Reality}

In an ideal system, every prosecutor and judge would have what is commonly known as a Gladue Report submitted before sentencing a First Nations person. These reports describe the particular experience and circumstances of First Nations people before the courts. ${ }^{11}$ In so doing, the reports explain what other sentencing options might address the unique issues contributing to that person being before the court. ${ }^{12}$ The reports are commonly drafted with someone who is connected to, and intricately understands, the offender's First Nations community. ${ }^{13}$ This ensures that the court receives the most relevant information possible before passing sentence.

Despite assumptions by the Supreme Court of Canada that Gladue Reports are commonly provided to those involved in the sentencing process, ${ }^{14}$ this is often not the case. ${ }^{15}$ In Saskatchewan, for instance, Gladue Reports are hardly requested for at least two reasons. First, there is a lack of report writers. ${ }^{16}$ As recent as March of 2018, Saskatchewan had only one Gladue Report writer on staff. ${ }^{17}$ Second, recent funding cuts ${ }^{18}$ to Saskatchewan's Legal Aid are also likely to adversely affect the ability of counsel to rely upon Gladue Reports. ${ }^{19}$ As several authors have observed, these funding cuts make already overworked and underfunded Legal Aid lawyers even more hard pressed to obtain and rely upon Gladue reports in sentencing. ${ }^{20}$

Although judges may partially rectify this problem by requesting regular pre-sentence reports, these reports differ substantially from Gladue reports. Pre-sentence reports are issued under a different section of the Criminal Code, ${ }^{21}$ and are prepared by a probation officer who generally will not have specialized training with respect to local Aboriginal cultures. ${ }^{22}$ Their reports, per section 721(3) of the Criminal Code, are primarily designed to assess propensity to reoffend. ${ }^{23}$ Although courts may ask probation officers to pay particular attention to Gladue fac- tors, ${ }^{24}$ there is no guarantee that they are able to provide meaningful analysis. This is a key distinguishing feature between Gladue reports and pre-sentence reports. As one author observes, "[a] Gladue report will put your particular situation into an Aboriginal context so that the judge can come up with a sentence that's unique to you and your culture". ${ }^{25}$

One might also think that lawyers frequently discuss the background of offenders before making sentencing submissions. Although this is likely to happen in well-funded criminal justice systems, it is my experience as a former Crown Prosecutor that this generally did not occur unless the sentence was likely to be significant. ${ }^{26}$ Again, the fact that Legal Aid and other defence counsel are extremely busy and generally underfunded might explain this in part. The Crown might also fail to discuss the offender's circumstances adequately because of time pressures. Another factor might be a lack of trust in the Crown Prosecutor. Perhaps some defence counsel and offenders think Crown Prosecutors will use information about a First Nations person's background against them somehow. ${ }^{27}$ Regardless of the reason, the fact remains that Crown Prosecutors will often not know of the offender's circumstances before stepping into the courtroom.

This leads to an awkward circumstance. Picture a docket court with a single Crown Prosecutor standing beside a large stack of files. Some of these cases have been discussed with opposing counsel, but many have not been discussed in any detail. Other cases concern people who cannot (or will not) obtain a lawyer and instead plan on pleading guilty that day. As we know, a significant amount of the people coming through the criminal justice system are of First Nations background. Of those First Nations people that will be sentenced, many (whether personally or via their counsel) will therefore not have had more than a passing discussion with the Crown Prosecutor about factors relevant to sentencing a First Nations offender. Instead, those facts come out either when (i) defence counsel makes his or her submissions to the court; and/or (ii) the judge asks the offender questions directly related to his or her past experiences. 


\section{Problematizing the Order of Sentencing Submissions}

The foregoing discussion suggests that the Crown Prosecutor will often not know about many First Nations offenders' background when providing its sentencing submissions. Even in cases where a Gladue Report is submitted, however, it need not follow that the offender will know that the Crown Prosecutor was made aware of that report. This depends on whether the offender made such an inquiry, either by asking the Gladue Report writer or his or her counsel, or if the Crown cites the report in his or her submissions. If this does not occur, the offender could reasonably hold the view that the Crown Prosecutor does not know about his or her circumstances before reciting the facts underlying the offence and recommending a sentence.

With this background in mind, put yourself in the place of a First Nations person about to be sentenced. Perhaps they have heard of section 718.2(e) of the Criminal Code and the Gladue and Ipeelee decisions. If not, it is reasonable to believe that First Nations people generally know of the injustices brought upon their people throughout the history of the Canadian criminal justice system. Now, the Crown Prosecutor, about to provide the court with sentencing submissions, is going through the facts of the offence and recommending sentence without demonstrating any knowledge about the personal circumstances of the First Nations person being sentenced. Surely, one would expect that the Crown Prosecutor could have found out more about the offender. Perhaps they were too busy. Or perhaps they do not care. In my experience, Crown Prosecutors do care. However, when dealing with a population that has many reasons to distrust the state, the optics of the sentencing procedure will speak louder than the often-unexpressed empathy of individual Crown Prosecutors.

Requiring that defence counsel first make submissions about the First Nations person's background would ensure that the Crown Prosecutor would hear about the relevant Gladue factors before making his or her submissions. No doubt many, if not all, Crown Prosecutors would take these considerations into account in their submissions to the court. In these circumstances, the First Nations person being sentenced would see that the state representative listened to their story, engaged with their story, and allowed their story to affect the ultimate sentence the state proposes. Such a change in approach fits well with the idea of reconciliation more generally. As the Alberta Court of Appeal recently affirmed in $R$ $v$ Wolfleg, ${ }^{28}$ "[f]idelity to the values underpinning [the Gladue principle] is instrumental to the advancement of reconciliation with all Indigenous peoples." ${ }^{29}$ Those values, I suggest, should not just affect the determination of the appropriate sentence, but also the process employed for sentencing First Nations peoples.

\section{Sentencing as Dialogue}

The above discussion embraces an approach that might be called "sentencing as dialogue." To truly transform the sentencing procedure into a dialogue, the Crown should be allowed to take an active role in asking questions meant to identify relevant factors about a First Nations person's past. Participation in such discussions before making submissions on sentence would show that the Crown Prosecutor is working towards a just outcome. Naturally, defence counsel (or the judge in instances of a self-represented offender) could maintain a screening role as to whether such questions should be answered. Alternatively, the offender could be told that he or she need not reply to the Crown Prosecutor's questions. However, in cases where all parties asked and answered questions in good faith, this approach would better contribute to repairing the relationship between First Nations people and the criminal justice system.

The dialogical approach would require significant effort from offenders and defence counsel alike. Defence counsel obviously have a duty to raise Gladue factors before the courts. ${ }^{30}$ This requires rigorous inquiry before sentencing occurs. As defence counsel are often pressed for time, they may have to employ innovative strategies for coming to a better understanding of their clients' First Nations background. One former defence counsel turned judge would have 
his clients write down their responses to relevant questions for his review. He would then use these writings alongside other relevant information in submissions at sentencing. In his view, this not only allows for more effective representation of First Nations people at sentencing, it also promotes responsibility in the individual offender as it requires that they reflect on the circumstances in their life that have contributed to their offending.

The above proposal, I suggest, would infuse reconciliatory principles into the sentencing process. It would ensure that the experiences of First Nations people are made central to the sentencing process, and that all parties are required to assess these important considerations before discussing potential punishments. This procedure need not, however, be limited to First Nations persons. Indeed, state representatives in the criminal justice system should be seen to engage with all factors relevant to sentencing every type of offender. Although such engagement is most pressing when it comes to sentencing First Nation people, I can see no reason why its use ought not be expanded to include all other offenders.

It may be retorted that the proposal here is a mere "band-aid" solution to a more systemic problem. As Gina Starblanket aptly observes in her article appearing in this issue, criminal justice issues are arguably much better resolved via recognizing First Nations people's authority over their own processes respecting criminal justice and other areas. Although there is much to commend this view, history suggests that we are unfortunately some distance away from moving to such a system of criminal law. Until such a point arises, it is still of the utmost importance that we think about ways of improving the Anglo-American criminal law structure of sentencing for those persons most profoundly affected by it.

\section{Conclusion}

Those critical of the Canadian criminal justice system have rightly called attention to the overincarceration of First Nations people. ${ }^{31}$ Efforts to address this pressing social issue must not only continue, they must increase significantly if a meaningful impact is to occur. ${ }^{32}$ Yet, amidst this focus on reforming substantive sentencing principles, the process in which we sentence the vast majority of people has not received significant criticism. In this article, I have argued that the procedure used to sentence offenders can also play an important role in rebuilding relations between the state and First Nations people. By embracing a dialogical approach to sentencing, it is my hope that First Nations people will be more likely to view the Crown Prosecutor as working towards a just outcome than as an adversary continuing to perpetuate historical injustices.

\section{Endnotes}

* PhD Student and Sessional Instructor at the University of Alberta, Faculty of Law

1 RSC 1985, c C-46.

2 Ibid, s 718.

3 Ibid.

4 Ibid, s 718.1.

5 See $R v$ Ipeelee, 2012 SCC 13 at para 37, [2012] 1 SCR 433.

6 [1999] 1 SCR 688, $171 \operatorname{DLR}\left(4^{\text {th }}\right) 385$.

7 Supra note 5.

8 See both decisions generally.

9 See Gladue, supra note 6 at para 64; Ipeelee, supra note 5 at para 58 ("The figures are stark and reflect what may fairly be termed a crisis in the Canadian criminal justice system. The drastic overrepresentation of aboriginal peoples within both the Canadian prison population and the criminal justice system reveals a sad and pressing social problem").

10 This much was made clear by the recent recommendations of the Truth and Reconciliation Commission of Canada. See "Truth and Reconciliation Commission of Canada: Calls to Action" (Winnipeg: Truth and Reconciliation Commission, 2015). As the Commission observed, despite representing only three percent of the population, First Nations people made up twentyfive percent of the prison population in 2015. See also Julie Reitano, Adult Correctional Services in Canada, 2014/2015 (Ottawa: Statistics Canada, 2016). 
11 See Jay Istvanffy, Gladue Primer (Victoria: Legal Services Society of British Columbia, 2011) at 6. See also Ipeelee, supra note 5 at para 60.

12 See Istvanffy, supra note 11 at 6.

13 Ibid at 7.

14 The Court in Ipeelee, supra note 5 at para 60 notes that "it appears" that submission of Gladue Reports is the current practice. However, no studies were cited in support of this point.

15 If anything, the evidence in some places is directly to the contrary. See Bre McAdam, "Gladue Reports Need to Be Done': Report Writer Calls for Network in Sask." The Star Phoenix (5 March 2018), online: <https://thestarphoenix.com/news/ local-news/sask-gladue-report-writer-calls-formore-writers-in-province $>$; Meaghan Craig, "Only Gladue Writer in Sask.: 'The People that are Needing Them are not Getting Them" Global News (1 March 2018), online: <https:/globalnews. $\mathrm{ca} / \mathrm{news} / 4054625$ /gladue-report-writersaskatchewan/>.

16 Ibid.

17 Ibid.

18 See Sarah Buhler \& Leif Jensen, "Opinion: Legal Aid Should Be Expanded, Not Cut" Regina Leader Post (1 August 2018), online: <https://leaderpost. com/opinion/columnists/opinion-legal-aidshould-be-expanded-not-cut $>$. This is also true in other parts of Western Canada. See Shawn Logan, "Defence Lawyers Say Legal Aid 'Neglected and Degraded' in Alberta" Calgary Herald (30 April 2018), online: <http://calgaryherald.com/ news/local-news/defence-lawyers-says-legalaid-suffering-from-funding-crisis-in-alberta>; Lauren Krugel, "Alberta Defence Lawyers Demand Boost to Legal Aid Funding" The Globe and Mail (17 April 2018), online: <https://www. theglobeandmail.com/canada/alberta/articlecalgary-defence-lawyers-group-demands-boostto-legal-aid-funding/>; Ian Burns, "B.C. Budget Boosts Legal Aid Funding but it's still 'Woefully Underfunded,' Women's Equality Group says" The Lawyer's Daily (26 February 2018), online: $<$ https://www.thelawyersdaily.ca/articles/5971/bc-budget-boosts-legal-aid-funding-but-it-s-stillwoefullyunderfunded-women-s-equality-groupsays $>$.

19 As James Scott recently observed in his article "Reforming Saskatchewan's Biased Sentencing Regime" (2017) 65 Criminal Law Quarterly 91, "Gladue reports are costly and Legal Aid Saskatchewan needs to ration its resources, including Gladue reports, based on certain criteria." Others have also observed the negative affect funding has had on the availability of Gladue Reports. See Alexandra Hiebert, "Change in Paradigm or Change in Paradox? Gladue Report Practices and Access to Justice” (2017) 43 Queen's Law Journal 149; Tim Quigley, "Gladue Reports: Some Issues and Proposals” (2016) 31 Criminal Reports (7th) 405.

$20 \mathrm{Ibid}$. It is important to note that in no way am I saying that Gladue Reports are unimportant. They can prove instrumental in achieving just results when sentencing First Nations offenders. The point is that they may not always be feasible (supra note 19), and even when submitted will not always address the problem that I seek to address in this article. The latter point will be expanded upon below.

21 See section 721.

22 See Istvanffy, supra note 11 at 7 describing section 721(3) of the Criminal Code.

23 Ibid.

24 See section 721(4) of the Criminal Code.

25 See Istvanffy, supra note 11 at 7

26 I was a Crown Prosecutor in Regina, Saskatchewan, and also a Law Clerk for the Provincial Court of Saskatchewan. Although my evidence is anecdotal, it should not be surprising given the underfunding of Legal Aid in Saskatchewan. See also Buhler \& Jensen, "Legal Aid", supra note 18.

27 This is speculative on my behalf. Anecdotally, however, I had difficulty rationalizing why defence counsel would sometimes refuse to discuss a First Nations persons' background in detail with me and other prosecutors. A heavy schedule is at least offset somewhat by the potential for resolving a sentence before appearing in court.

282018 ABCA 222, Alta LR $\left(6^{\text {th }}\right) 45$.

29 Ibid at para 101.

30 See Ipeelee, supra note 5 at para 60. First Nations persons may, however, waive their right to have Gladue factors considered.

31 See Gladue, supra note 6 at para 64; Ipeelee, supra note 5 at para 58

32 See generally Truth and Reconciliation Commission of Canada, supra note 10. 
